\title{
Tracking The Status of Forest Rights Act, 2006 and its Impact on the Livelihood of Tribal Communities in Wayanad District of Kerala, India
}

\author{
Merlin Mathew* and K.B. Umesh
}

Department of Agricultural Economics, University of Agricultural Sciences, Bengaluru, India

Corresponding author: merlin0703@gmail.com (ORCID ID: 0000-0002-0502-6504)

Received: 14-04-2019

Revised: $17-07-2019$

Accepted: 25-08-2019

\begin{abstract}
Tribal population is the aboriginal inhabitants of India who have been living a life based on the natural environment and have cultural patterns congenial to their physical and social environment. Realizing the disadvantage position of forest dwelling communities, Government of India passed The Schedule Tribe and Other Traditional Forest Dwellers (Recognition of Forest Rights) Act, 2006 (FRA). The act aims at granting legal entitlement, empowerment and improvement of livelihood by way of various provisions of the act, but due to lack of proper awareness and impediments in the implementation this goal was not fully achieved. The present study was conducted in the tribal majority district of Kerala, Wayanad, where FRA was implemented to strengthen the social security and livelihood improvement of forest dwelling communities. This study attempts to enlighten the status and progress of FRA in Wayanad along with its impact on the major tribal communities. The assessment of impact on socio-economic and livelihood improvement was done based on the primary data collected from 160 households of four tribal communities viz., Paniya, Kuruma, Kattunaika, and Urali, which are the predominant communities found in the study area. Study revealed that Kuruma community found to have 'very good' socio-economic condition after the implementation of Act. There are positive outcomes in terms of socio-economic status and livelihood progress of other communities as well but the difficulties in realizing rights and utilizing it lead to the poor impact of FRA, 2006 on them.
\end{abstract}

\section{Highlights}

(0 Even after 11 years of implementation of FRA, 2006, the impact of act remains meager among the major beneficiaries due to lack of awareness and defective governance.

Keywords: FRA, 2006, Individual Land Rights (ILR), Community Right, Developmental Rights, Tribal livelihood

Tribals or 'Adivasis', are the aboriginal inhabitants of the World. Since time immemorial they have had an integral and close knit relationship with the forest and have been dependent on the forest for livelihoods and existence. Indian forests are home to 8.2 per cent of the nation's population and it is over 84 million people according to 2011 census. Even though they were leading a symbiotic relationship with the forests their customary rights for living, possessing and earning livelihood from the forests were not recognized properly. The suffering for the tribals in every way, especially their right to livelihoods besides disturbing the traditional forms of conservation and management of forest ecosystem started during the early $19^{\text {th }}$ century itself when the colonial regime was ruling the country. This injustice was continued even after the independence in the name of conservation and protection of forests. Ever since, they have been living under the threat of eviction, because of the Indian forest legislature was inadequate in addressing the rights of the tribal. This "historical 
AESRA

injustice" has also led to alienation of tribals from their ancestral land which has weakened their social and economic status (Anitha et al. 2015).

As most of the tribals live in the forest and natural environment which are far away from the civilized societies, their socioeconomic status is so poor that it warranted a concerted effort on the part of the Government. Further, inadequacy of constitutional safeguards for the tribal communities has made them one of the most vulnerable and exploited communities in India. Realizing the disadvantage position of the tribal communities, the Central Government passed a bill to formulate "Recognition of Forest Rights Act 2006" to protect the interests of tribal communities (Anitha et al. 2015). The Act aims at making amends to historical injustice establish clear property rights; develop synergistic opportunities between sustainable livelihoods and conservation and community empowerment (Madhusudan, 2012).

The progress of implementation has been slow all over India even after 11 years of its implementation (Aggarwal, 2012). The correct and timely implementation of the Act would have made the forest dwelling tribals a major stakeholder of forest management and also improved their socio-economic conditions. But the results of the implementation in terms of management of forest resource and improvement in living conditions of forest dwelling tribal communities is far from what was initially conceived as the implementation is marred with various issues. Thus it becomes important to critically assess the progress of implementation of FRA in various states in India so that the implementation process can be improved and can contribute to the welfare and development of the tribal communities.

The present study examines the implementation of FRA in Wayand district of Kerala which is one of the better performing states in the country when it comes to the promise and performance of FRA, 2006 (Anonymous, 2016). The paper is based on the results of empirical study undertaken in Wayanad and throws light on whether a right based regime can contribute to livelihood improvement by assessing the impact on the socio-economic development of the tribals after the implementation of the Act. At present, there is no comprehensive study that analysed the implementation of FRA and its impact on livelihood of tribals in Wayanad thus it becomes important to bring forward the ground realities and issues which can be the possible causes of poor implementation and can form basis of learning for other states in India.

\section{Forest Rights Act, 2006 (FRA)}

In its preamble, the scheduled Tribes and Other traditional Forest Dwellers (Recognition of Forest rights) Act, 2006, recognizes the historical injustice meted out to Scheduled Tribes and other traditional forest dwellers. It seeks to secure traditional rights over forest land and community forest resources and establish democratic community based forest governance.

FRA recognizes 14 pre-existing rights of forest dwellers on all categories of forestland, including protected areas. The major rights are:

- Individual Forest Rights (IFRs) and Community Rights (CRs) of use and access to forest land and resources;

- Community Forest Resource (CFR) Rights to use, manage and govern forests within the traditional boundaries of villages; and

- Empowerment of right-holders, and the Gramasabha, for the conservation and protection of forests, wildlife and biodiversity, and their natural and cultural heritage (Section 5, FRA)

Developmental rights, the FRA also provides powers to the Government for diverting forest land to build schools, dispensaries, anganwadies, fair price shops, electric and telecommunication lines, drinking water facilities, etc. However, the FRA makes it clear that the forest land, which can be diverted for other uses, is less than one hectare (for any single use) provided the felling of trees does not exceeds 75 trees per hectare.

\section{Objectives of the study}

The objective of the study is to assess the progress and status of FRA implementation in the Wayanad district of Kerala and analyse the impact of act on the livelihood and socio-economic improvement of tribal population in the area. Since only few Community forest rights have been vested in the district, the focus of study is on the Individual Land Rights which is mainly concerned with the securing of livelihood of tribal communities. The 
specific research objectives pertaining to the study are,to assess the status and progress of FRA, 2006 in Wayanad andto analyse the impact of FRA, 2006 on the socio economic and livelihood aspects of different tribal communities in Wayanad.

\section{DATA AND METHODOLOGY}

The data for the study was collected through interactions with various stakeholders like the Government officials responsible for the implementation at the state level including officials of the welfare department, forest department, panchayath offices, Kerala institute for Research Training \& Development studies of Scheduled Castes and Scheduled Tribes (KIRTADS), tribal societies and tribals. For addressing the research questions secondary data was collected from Wayanad Wildlife Division, Sulthan Bathery, Integrated Tribal Development Office (ITDP), Kalpetta, published literatures, newspaper articles, Government and non- government reports etc. For the second part, a primary questionnaire survey of tribal households, vested with Individual Land Right (ILR) was conducted by authors in the year 2018. A total of 160 households were surveyed in the four ranges selected from the district and from each range, 40 households belongs to four dominant communities in the study area were selected (Table 1 ). The households selected were on the basis of random sampling. The basis for selecting the ranges are, number of Scheduled Tribes residing in the area vested with the FRA titles and safety and accessibility to conduct study.

Table 1: Sampling structure (In numbers)

\begin{tabular}{cccccc}
\hline \multirow{2}{*}{ Ranges } & \multicolumn{3}{c}{ Tribal communities } & Total \\
\cline { 2 - 6 } & Kattunaickka & Urali & Paniya & Kuruma \\
\hline Kurichiyatt & 10 & 10 & 10 & 10 & 40 \\
Muthanga & 10 & 10 & 10 & 10 & 40 \\
Sulthan & 10 & 10 & 10 & 10 & 40 \\
Bathery & 10 & 10 & 10 & 10 & 40 \\
Tholpetty & $\mathbf{4 0}$ & $\mathbf{4 0}$ & $\mathbf{4 0}$ & $\mathbf{4 0}$ & $\mathbf{1 6 0}$ \\
\hline Total & & & & &
\end{tabular}

\section{Development of the socio-economic framework}

In order to capture the impact of FRA, 2006 on the various tribal communities a socio economic framework was developed in line with the work of
Khosla and Bhattacharya (2018). Various descriptive indicators, indicators for livelihood improvement and indicators for socio-economic improvement are considered in the study in consultation with various experts and stakeholders of the act.

\section{Selection of appropriate indicators}

Ravindranath et al. (2011) have used Principal Component Analysis (PCA) to identify the significant indicators and eliminate non-significant indicators. As recommended by Harman (1967), only factor loadings of 0.3 or more were considered as significant. The selected 20 indicators obtained the factor loadings of more than 0.3. For the present study cut-off value of the communality values were also decided as 0.30. Surprisingly, all the 20 indicators maintained the communality values more than the cut off 0.40 . Thus no indicators were rejected at this point of analysis. The mean communality value of the 20 indicators after extraction was more than 0.70 (Table 3 ).

\section{Assignment of weights to the indicators}

Kaiser normalisation and scree plot were used to identify the initial eigenvalues greater than one. According to the number of eigenvalues greater than one, the same numbers of components were extracted by using varimax rotational method for each indicator. Then, the method followed by Feroze and Chuhan (2010) was adopted for this study to assign the weights to the indicators. The initial eigenvalues above one were identified.

According to the number of eigenvalues above one, the same numbers of rotated components were extracted for each variable. Now, the extracted rotated component matrix was multiplied by the eigenvalues, i.e., the 1st eigenvalue was multiplied with the 1st extracted component column and $2^{\text {nd }}$ eigenvalue was multiplied with the $2^{\text {nd }}$ extracted component column, considering only absolute values. The values obtained were added in case of each indicator to get the weight for that particular indicator. Similarly, weights were obtained for all other indicators.). Weights of 20 indicators were further tabulated (Table 2). The importance of identified indicators was fixed according to their weightages and the indicators with higher weightage had the comparative importance than the indicator with lower weightage. 
Table 2: Communalities and weightage of indicators

\begin{tabular}{|c|c|c|c|c|c|}
\hline \multirow[t]{2}{*}{ No. } & \multirow[t]{2}{*}{ Parameter } & \multirow[t]{2}{*}{ Indicator } & \multicolumn{2}{|c|}{$\begin{array}{l}\text { First run of factor analysis } \\
\text { communalities }\end{array}$} & \multirow[t]{2}{*}{ Weightage } \\
\hline & & & Initial & Extraction & \\
\hline \multirow[t]{2}{*}{ P1. } & \multirow{2}{*}{$\begin{array}{c}\text { Stability of } \\
\text { Household structure }\end{array}$} & 1. Type of house & 1.000 & 0.699 & 2.630516 \\
\hline & & 2. Size of house & 1.000 & 0.783 & 4.280877 \\
\hline \multirow[t]{3}{*}{ P2. } & \multirow{3}{*}{ Basic infrastructure } & 3. Energy source & 1.000 & 0.626 & 3.120895 \\
\hline & & 4. Electricity & 1.000 & 0.556 & 2.834999 \\
\hline & & 5. Road facility & 1.000 & 0.440 & 3.503597 \\
\hline \multirow[t]{2}{*}{ P3 } & \multirow[t]{2}{*}{ Social participation } & $\begin{array}{l}\text { 6. Family members attending awareness classes on } \\
\text { FRA }\end{array}$ & 1.000 & 0.661 & 3.888208 \\
\hline & & $\begin{array}{l}\text { 7. Total memberships in social groups (NGO's }{ }^{1} \text {, } \\
\text { Kudumbasree, EDC }{ }^{2}, \mathrm{VSS}^{3} \text {, Gramapanchayatetc) }\end{array}$ & 1.000 & 0.678 & 3.094873 \\
\hline P4 & Area under IFR & 8. Size of IFR vested under FRA & 1.000 & 0.781 & 4.520546 \\
\hline \multirow[t]{3}{*}{ P5 } & \multirow[t]{3}{*}{ Asset structure } & 9. No. of consumer durables possessed by the family & 1.000 & 0.603 & 3.92322 \\
\hline & & 10. Farm assets possessed by the family & 1.000 & 0.759 & 4.900196 \\
\hline & & 11. Livestock possessed by the family & 1.000 & 0.750 & 2.336079 \\
\hline \multirow[t]{3}{*}{ P6 } & \multirow[t]{3}{*}{ Income diversification } & 12. Income from agriculture and livestock & 1.000 & 0.802 & 4.512171 \\
\hline & & $\begin{array}{l}\text { 13. Income from forest related activities (Vista } \\
\text { clearing, fire line making, anti-pouching camp, } \\
\text { watcher etc.) }\end{array}$ & 1.000 & 0.825 & 2.42749 \\
\hline & & 14. Income from NTFP & 1.000 & 0.889 & 3.136444 \\
\hline \multirow[t]{4}{*}{ P7 } & \multirow{4}{*}{$\begin{array}{l}\text { Employment } \\
\text { opportunities }\end{array}$} & 15. Employment form agriculture and livestock & 1.000 & 0.835 & 4.322834 \\
\hline & & 16. Agricultural labour & 1.000 & 0.696 & 4.479464 \\
\hline & & $\begin{array}{l}\text { 17. Forest related activities (Vista clearing, fire line } \\
\text { making, anti-pouching camp, watcher etc) }\end{array}$ & 1.000 & 0.914 & 3.344883 \\
\hline & & 18. NTFP collection & 1.000 & 0.782 & 2.152296 \\
\hline P8 & Literacy rate & 19. Education of the respondent & 1.000 & 0.674 & 3.206742 \\
\hline P9 & Family size & 20. No. of family members & 1.000 & 0.840 & 1.598358 \\
\hline
\end{tabular}

${ }^{1}$ Non-Governmental Organisations ${ }^{2}$ Eco-Development Committee ${ }^{3}$ Vana Samrakshana Samithi.

\section{Normalisation of data}

The indicators have to be normalised to bring the values within a comparable range. (Piya et al. 2012). Min-Max method of normalisation was adopted for the study (Feroze and Chauhan, 2010). Normalization was done by subtracting the minimum value from the observed value and dividing by range.

\section{Computation of the composite score}

The normalised indicators were then multiplied with the assigned weights to construct the index scores separately for 20 indicators. Then sum of each multiplication was divided by the grand total weight to obtain the index. Overall composite score was developed with the following formula.

$$
\text { Composite score }=\frac{\sum_{i=1}^{n} x_{i}\left[\sum_{j=1}^{n} E_{j}\left|L_{i j}\right|\right]}{\sum_{i=1}^{n}\left[\sum_{y=1}^{n} E_{j}\left|L i_{j}\right|\right]} * 100
$$

Where $x_{i}$ is the normalized value of $i^{\text {th }}$ indicator; $L_{i j}$ is the factor loading of the $i^{\text {th }}$ variable on $j^{\text {th }}$ factor; $E_{j}$ is the Eigen value of $j^{\text {th }}$ factor. The grand total weight for 32 indicators was 68.22.

Table 3: Scheme of classification

\begin{tabular}{cc}
\hline Scheme of classification & Class status \\
\hline$>\mu+$ sd & Very good \\
$\mu+$ sd to $\mu$ & Good \\
$\mu-$ sd to $\mu$ & Fair \\
$<\mu-$ sd & Bad \\
\hline
\end{tabular}

The status of beneficiaries of FRA, 2006 was calculated with the above given index formula. 
Further, the respondents were classified into four categories (Table 3), method followed by Khosla and Bhattacharya, 2018.

\section{RESULTS AND DISCUSSION}

This section has been organized in two parts, the first part deals with the first research objective of status and progress of implementation of FRA in Wayanad district in terms of right vested. The second part incorporates the result of primary survey pertaining to the various indicators of the Individual Land Right (ILR) vested households thereby assess their socio-economic and livelihood conditions, pertaining to the second objective.

\section{(I) progress of FRA in Wayanad}

Wayanad the panoramic hill of Malabar in the northern Kerala is a homeland of various tribal communities. In Kerala, it is the district with the highest percentage of Scheduled Tribe population - $18.5 \%$ as compared to $1.14 \%$ for the state as a whole (Census, 2011). These communities are always susceptible to exploitation and are largely marginalized due to their inherent disadvantaged social strata. Story of adivasi land alienation in Wayanad goes back to the late $14^{\text {th }}$ to early $15^{\text {th }}$ century, when the tribal kingdom under the Vedar kings (Mullu Kurumar) was abolished by the rajas of Kottayam, a neighbouring chiefdom.(Munster and Vishnudas, 2012). The continued land dispossession and violent alienation made Wayanad's adivasis a predominately landless labourers today, living in overcrowded colonies, with Adiyar, Paniyar, Kattunaikar and Urali Kurumar belonging to the poorest section of Wayanad's society, most vulnerable to exploitation and structural violence .As most of them live in the forest and natural environments which are far away from the civilized societies, their socioeconomic status is so poor that it warranted a concerted effort on the part of the state. Therefore in order to make amends to historical injustice, establish clear property rights, develop synergistic opportunities between sustainable livelihoods and conservation and community empowerment FRA was implemented in the state.

Even though the passing of act was accompanied by enormous criticism, Kerala was one of the state Governments to complete the implementation process of FRA in the country (Sathyapalan, 2010). The implementation of FRA was a huge bureaucratic project. To monitor the implementation state Government was requested to form a Subdivisional Level Committee (SDLC), a District Level Committee, a State Level Monitoring Committee (SLMC) and at the ground level Forest rights Committee (FRC). Tribal welfare department is the nodal agency to coordinate the implementation process.

According to the official records as on December 2018, after a eleven yearlong implementation process, majority of the forest dwelling community in the Wayanad district received a FRA land possession certificate, at least for the land upon which their houses stands. For the proper implementation of FRA, 2006, 109 Forest rights Committees were constituted in the district, highest among all the districts of Kerala. Out of the total 7918 individual land right claims received, 4365 (55.12\%) titles were issued in Wayanad for an area of 3312.27 hectares. Whereas in case of community rights out of 321 claims received only 124 (38\%) granted titles for the rights (Table 4).

Rejection at the Grama Sabha level were highest, out of the total claims received 74.20 per cent was passed during the initial verification process and 55.12 per cent of the total claims were distributed in the district. During the interview with the concerned departmental officials it was observed

Table 4: Progress of FRA, 2006 in Wayanad, as on December 2018- Individual rights (ILR) and community rights

\begin{tabular}{cccccccc}
\hline Titles & FRCs & Claims filed & $\begin{array}{c}\text { Passed by } \\
\text { Gramasabha }\end{array}$ & $\begin{array}{c}\text { Passed by } \\
\text { SDLC }\end{array}$ & $\begin{array}{c}\text { Passed by } \\
\text { DLC }\end{array}$ & Granted titles & $\begin{array}{c}\text { Extent of land for } \\
\text { which titles given } \\
\text { (Hectares) }\end{array}$ \\
\hline Individual & \multirow{2}{*}{ Go } & 7918 & 5875 & 4450 & 4450 & 4365 & 3312.2 \\
& & $(74.20)$ & $(56.20)$ & $(56.20)$ & $(55.12)$ & - \\
\hline
\end{tabular}

Figures in the parentheses indicate percentage to the total claims filed. 


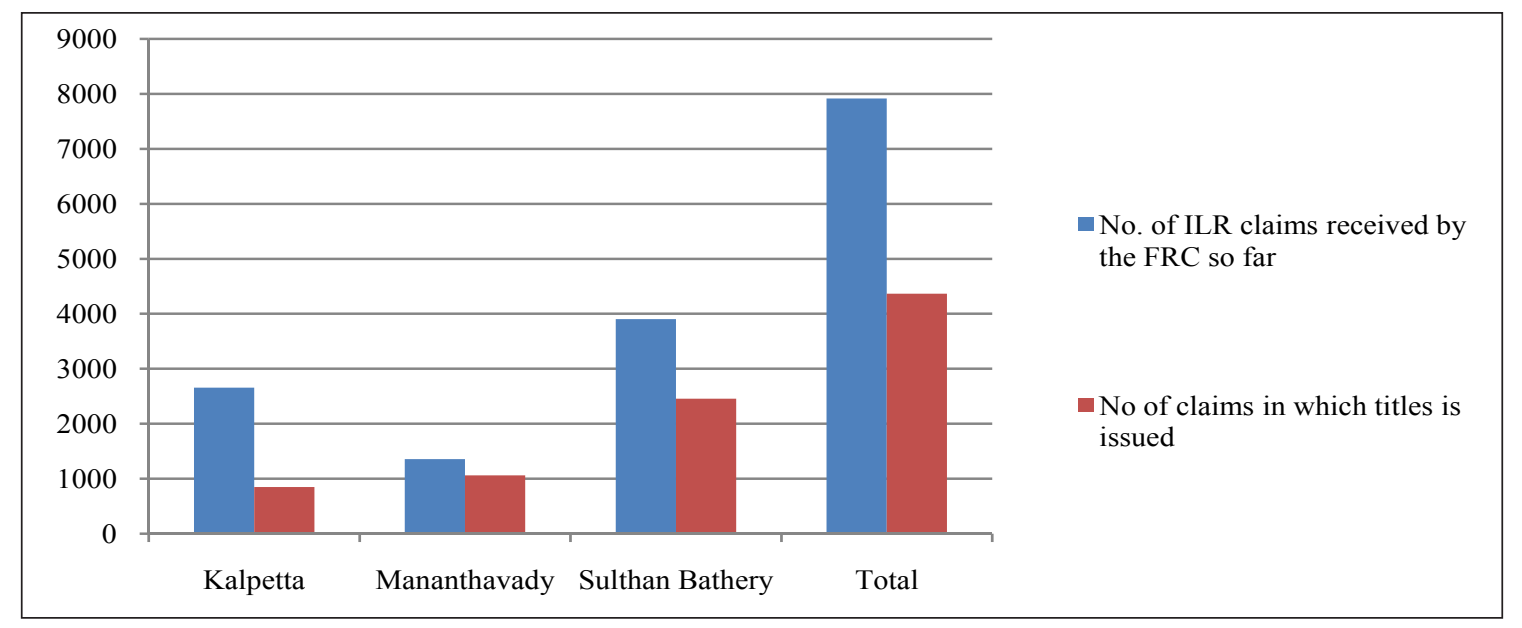

Fig. 1: Distribution of ILR rights in the Wayand district-blockwise

that the numbers of potential ILR households in the districts are unknown even now. Among the three blocks in Wayanad, Sulthan Bathery has the maximum number of ILR title holders followed by Mananthavady and Kalpetta (Fig. 1).

Table 5: Progress report of FRA, 2006 as on December 2018- Developmental rights

\begin{tabular}{|c|c|c|c|c|c|c|c|c|}
\hline 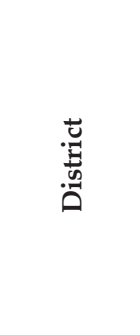 & 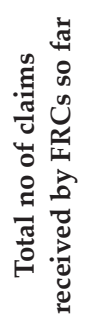 & 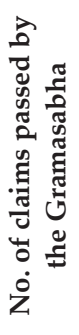 & 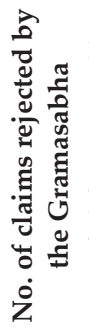 & 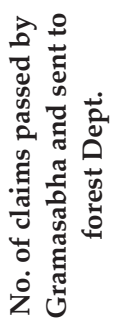 & 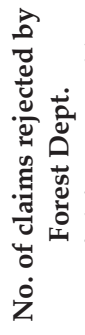 & 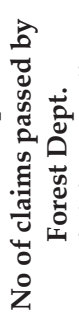 & 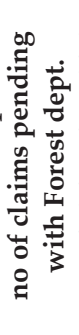 & 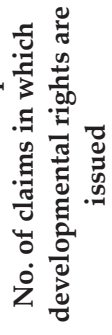 \\
\hline Wayanad & 176 & 176 & Nill & 176 & 12 & 159 & 5 & $\begin{array}{c}159 \\
(90.34)\end{array}$ \\
\hline
\end{tabular}

FRA also give authority to the state Government to convert the forest land to build schools, dispensaries, anganwadies, fair price shops, electric and telecommunication lines, drinking water facilities etc. for the development of tribal settlements. There were 176 developmental right claims filed with the
FRCs and 90.34 per cent of them cleared by the forest department. None of the claims were rejected at the Gramasabha level (Table 5).

The ranges wise distribution of Developmental activities taken up by the tribal department showed that,all these activities were taken up with minimum damage to the forest area and maximum numbers of activities were taken up in Sulthan Bathery range. Out of the total individual land rights, community rights and developmental rights distributed in the state of Kerala, Wayanad is the leading district in the implementation of FRA, 2006 with highest population of tribal communities. But as far as the number and extent of rights delivered to the potential households performance is poor in the recent years due to asymmetric information flow, deficient coordination, undemocratic participation, dearth of transparency and lack of accountability at various levels of implementation which claims to safeguard the basic rights of disempowered local people. Bijayashree, 2017 also concluded the similar reasons for poor implementation and progress of FRA, 2006 in Odisha.

Table 6: Developmental rights under FRA, 2006 range wise (2008-2018)

\begin{tabular}{ccccc}
\hline Range & $\begin{array}{c}\text { No. of activities* } \\
\text { taken up }\end{array}$ & $\begin{array}{c}\text { Total forest Area } \\
\text { allocated (Hectares) }\end{array}$ & No of beneficiaries & No. of trees cut \\
\hline Tholpetty & 18 & 2.28 & 989 & 1 \\
Kurichiat & 17 & 3.61 & 528 & 0 \\
Sulthan Bathery & 33 & 3.54 & 1996 & 77 \\
Muthanga & 20 & 2.78 & 730 \\
\hline
\end{tabular}

*Electrification, check dam construction, soling of colony, Anganwadi construction, irrigation canal, bus waiting shed, drainage and culvert construction. 


\section{(II) Impact of FRA on tribals socio-economic attributes and livelihood}

In order to understand the impact of this act on the livelihood of tribal communities', households were selected from four major tribal communities belonging to four ranges that cover both Sulthan Bathery and Manathavady blocks of Wayanad district where the maximum number of titles are being distributed.

Attributes of the community is a set of variable that affects the arena of implementing the act (Sathyaplan, 2010). The attributes such as size and composition of relevant community, the extent of inequality of basic assets, cultural practices followed by them and their traditional occupation has a bearing on the realization of act provisions. Therefore socioeconomic frame work was constructed for major tribe groups in the study area viz., Kattunaicka, Paniya, Urali, Kuruma. In order to assess the distributional equality of the act index was also constructed for each range.
The descriptive statistics of selected indicators for index construction is provided in Table 7.Stability of the household structure, size of the house, energy source, basic infrastructure facility, social participation, area under ILR, asset structure, income sources, employment generation, literacy, family size were the nine parameters selected for the socio-economic framework. Except family size and social participation all other indicators exhibited a significant difference between the tribal groups under study.

Uralis possessed the maximum number of concrete houses followed by the Kattunaickas. More than fifty per cent of all the communities possessed a pucca or concrete homes. It was a progressive result that showed the government efforts to build the basic amenities to all the marginalized sections of the country. Even though Kurumas were the community having less number of concrete houses, the size of their houses were comparatively large in size. They possessed traditional tiled houses of 30 to 40 years old.

Table 7: Descriptive statistics of the indicators selected for the study

\begin{tabular}{|c|c|c|c|c|c|}
\hline No & Indicator description & Kattunaikkan & Urali & Paniyan & Kuruma \\
\hline I & Stability of Household structure & & & & \\
\hline \multirow[t]{6}{*}{1.} & Type of the house & & & & \\
\hline & a. Huts & 0 & $3(7.5)$ & 0 & 0 \\
\hline & b. Katcha & $2(5)$ & $2(5)$ & $4(10)$ & 0 \\
\hline & c. Pucca & $14(35)$ & $8(20)$ & $17(42.5)$ & $23(57.5)$ \\
\hline & d. Concrete & $24(60)$ & $27(67.5)$ & $19(47.5)$ & $17(42.5)$ \\
\hline & $\chi^{2}=23.43^{* * *}$ & & & & \\
\hline \multirow[t]{6}{*}{2} & Size of the house & & & & \\
\hline & a. $100-200$ & 0 & $6(15)$ & $4(10)$ & 0 \\
\hline & b. $200-300$ & $12(30)$ & $1(2.5)$ & $10(25)$ & $2(5)$ \\
\hline & c. $300-400$ & $22(55)$ & $25(62.5)$ & $21(52.5)$ & $21(52.5)$ \\
\hline & d. $>400$ & $6(15)$ & $8(20)$ & $5(12.5)$ & $17(42.5)$ \\
\hline & $\chi^{2}=36.123^{* * *}$ & & & & \\
\hline \multirow[t]{6}{*}{3} & Energy source & & & & \\
\hline & a. Only fuel wood & $21(52.5)$ & $25(62.5)$ & $16(40)$ & $11(27.5)$ \\
\hline & b. Kerosene + fuel wood & $1(2.5)$ & $4(10)$ & $11(27.5)$ & 0 \\
\hline & c. LPG+ fuel wood & $16(40)$ & $9(22.5)$ & $11(27.5)$ & $29(72.5)$ \\
\hline & d. Only LPG & $2(5)$ & $2(5)$ & $2(5)$ & 0 \\
\hline & $\chi^{2}=41.51^{* * *}$ & & & & \\
\hline II & Basic infrastructure facility & & & & \\
\hline \multirow[t]{4}{*}{4} & Electricity & & & & \\
\hline & a. Yes & $1(2.5)$ & 0 & $7(17.5)$ & $5(12.5)$ \\
\hline & b. No & $39(97.5)$ & $40(100)$ & $33(82.5)$ & $35(87.5)$ \\
\hline & $\chi^{2}=10.97^{* *}$ & & & & \\
\hline
\end{tabular}




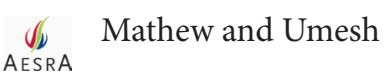

5 Road
a. Yes
$6(15)$
34 (85)
0
7 (17.5)
0
b. No
$40(100) \quad 33(82.5)$
40 (100)

$\chi^{2}=8.50^{* *}$

III. Social participation

6 Family members involved in forest related activities
a. Yes
$19(47.5)$
$20(50)$
$14(35)$
$21(52.5)$
b. No
$21(52.5)$
$20(50)$
$26(65)$
19 (47.5)

$\mathrm{F}=1.978$ (NS)

7 Total memberships in social groups (NGO's, Kudumbasree,

EDC,VSS, Grama panchayatetc)
a. Yes
$34(85)$
$33(82.5)$
$34(85)$
$37(92.5)$
b. No
$6(15)$
$7(17.5)$
$6(15)$
3 (7.5)
$\mathrm{F}=4.117^{* * *}$

\begin{tabular}{|c|c|c|c|c|c|}
\hline IV & Area under IFR & & & & \\
\hline 8 & $\begin{array}{l}\text { a. Size of IFR vested under FRA (Average in hectare) } \\
\mathrm{F}=11.758^{* * *}\end{array}$ & 0.263 & 0.235 & 0.064 & 0.377 \\
\hline $\mathrm{V}$ & Asset structure & & & & \\
\hline 9 & $\begin{array}{l}\text { No. of consumer durables possessed by the family } \\
\mathrm{F}=3.449^{* *}\end{array}$ & 2 & 3 & 2 & 4 \\
\hline 10 & $\begin{array}{l}\text { No. of farm assets possessed by the family } \\
F=2.960^{* * *}\end{array}$ & 5 & 5 & 4 & 7 \\
\hline VI & Income sources & & & & \\
\hline 12 & $\begin{array}{l}\text { Income from agriculture and livestock Rupees per annum) } \\
\mathrm{F}=5.965 * * *\end{array}$ & 8371.5 & 6725.25 & 3065.50 & 27671.28 \\
\hline 13 & $\begin{array}{l}\text { Income from forest related activities (Vista clearing, fire } \\
\text { line making, anti-pouching camp, watcher etc.) (Rupees } \\
\text { per annum) } \\
\mathrm{F}=3.057^{* * *}\end{array}$ & 14466 & 33502.5 & 3847.5 & 41661.54 \\
\hline 14 & $\begin{array}{l}\text { Income from NTFP (Rupees/ Annum) } \\
\mathrm{F}=2.703^{* * *}\end{array}$ & 12247.18 & 3671.25 & 10467.37 & 1489.74 \\
\hline VII & Employment generation & & & & \\
\hline 15 & $\begin{array}{l}\text { Employment form agriculture and livestock (Mandays/ } \\
\text { Annum) } \\
\mathrm{F}=2.732 * * *\end{array}$ & 16.25 & 10.10 & 1.35 & 39.13 \\
\hline 16 & $\begin{array}{l}\text { Agricultural labour (Mandays/Annum) } \\
\mathrm{F}=1.784^{* *}\end{array}$ & 83.21 & 83.40 & 72.82 & 32.12 \\
\hline 17 & $\begin{array}{l}\text { Forest related activities (Vista clearing, fire line making, } \\
\text { anti-pouching camp, watcher etc.) (Mandays/Annum) } \\
\mathrm{F}=2.328^{* * *}\end{array}$ & 39.85 & 123.6 & 11.58 & 85.51 \\
\hline & c. SSLC & $4(10)$ & $3(7.5)$ & 0 & $10(25)$ \\
\hline & $\begin{array}{l}\text { d. }>\text { SSLC } \\
\chi^{2}=21.50^{* *}\end{array}$ & $2(2.5)$ & 0 & 0 & $2(5)$ \\
\hline IX & Family size & & & & \\
\hline 20 & $\begin{array}{l}\text { No. of family members (Average) } \\
\mathrm{F}=0.513(\mathrm{NS})\end{array}$ & 4 & 3 & 3 & 3 \\
\hline
\end{tabular}

Note: ${ }^{* *}$ Significant at 1\% LOS ** Significant at $2 \%$ LOS Figures in the parenthesis indicate percentage to the total. 
Fuel wood was the major source of energy for all the communities except Kurumas. Only 27.5 per cent of them preferred fuel wood as the sole source of energy. More than 50 per cent of the Kattunaickka and Kuruma household's single source of energy was fuel wood. When it comes to the basic infrastructure facilities like transportation and electricity majority of the communities had access to both. Social participation parameter was restricted to participation in organizations that works in the line for the development of tribals like Oorukootam, attending FRA awareness classes, participation in Gramasabha, Vana Samrakshana Samithy (VSS) etc.

Results showed indifference among the communities with respect to the social participation. Almost 52.5 per cent of the Kuruma households were participating in different social activities followed by 50 per cent, 47.50 per cent and 35 per cent of the Urali, Kattunaickka and Paniya respectively. Memberships in social groups were as high as 92.50 per cent among the Kurumas. Overall asset structure of the household's in terms of consumer durables, farm machinery was also found highest among the Kuruma tribes, whereas livestock possession was highest among Paniyas.

Three major sources of incomes that directly come under the purview of FRA, 2006 was selected as the indicators. They were income from agriculture and livestock, income from forest activities such as vista clearing, anti-pouching, watcher etc. and income from NTFPs. The annual agriculture and livestock income was highest among the Kurumas (₹ 27671.28) followed by kattunaikka (₹ 8371.50), Uaali (₹ 6725.25) and Paniya (₹ 3065.50), least among all. Kuruma also realized a high income from forest activities since many of them were employed as permanent watchers. Urali households also realized a comparatively good income from forest activities. Employment generation from various sources was also considered for the socio-economic framework. Agriculture labour was the major source of employment for the majority of households. Education has a great role in the socio-economic development of the tribal population. Great amount of efforts are being taken up for the literacy improvement among them by local governments and NGO's in the state. The poor interest toward the educational attainment among the tribes is the biggest barrier in this context. Among the sample
57.50 per cent of the Paniyas were illiterate followed by 42.50 per cent of Kattunaickka. Kuruma and Urali comparatively performed better in educational attainment. The better education opportunities provided to the younger generation could open up new occupational opportunities and economic status for the indigenous people (Alex et al. 2017).

The composite index score (Table 8) of four communities as well as ranges showed that, among the communities, Kuruma tribes found to have the highest index score of 41.90 classified as very good according to the classification criteria followed by Khosla and Bhattacharya, 2018.Kurumaare the tribal community who believed to have descended from the Vedars, the ancient rulers of this region. Even though the community was mainly dealt with forest products, presently, most of them earn a livelihood thorough agriculture and cattle rearing. Parameter scores are high for Kuruma community that resulted in highest composite index score. In terms of stability of the household structure (P1), the income realized from the various sources especially from agriculture (P6) and the overall asset structure (P5) were especially high for them. They are the group with the highest average land holding among all other communities (Table 7). Kuruma is one of the higher castesamong the tribals of Kerala who were the traditional cultivators and whose average land holding is higher than the average landholding of all other communities in Wayanad (Munster and Vishnudas, 2012). It was one such community who had benefited even during, (Restriction of Transfer of Land \& Restoration of Alienated Land) act, 1975, came prior to FRA, 2006 for correcting the issues of land alienation due to the proper land titles they maintained due to the social advantage they bear as compared to other comparison groups. This study also ascertains the improved condition of these communities as compared to rest of the tribal groups. High literacy rate among them (70\% possess basic education)and the higher social participation has also resulted in better realization and utilization of land rights. Their involvement in NTFP collection was negligible but income generation from agriculture and livestock was significantly high as compared to other tribal communities. Legal right to cultivate on the forest land that they were cultivating before had made them better-off than the other communities. But 
Table 8: Socio-economic framework of the tribals- community wise and range wise

\begin{tabular}{ccccccccccccc}
\hline & Community & P1 & P2 & P3 & P4 & P5 & P6 & P7 & P8 & P9 & $\begin{array}{c}\text { Composite } \\
\text { score }\end{array}$ & Condition \\
\hline 1 & Kattunaickan & 8.63 & 8.42 & 3.70 & 1.33 & 5.35 & 1.51 & 5.40 & 1.21 & 0.86 & 36.41 & Good \\
2 & Urali & 8.17 & 8.26 & 3.73 & 1.18 & 6.43 & 1.28 & 5.67 & 1.10 & 0.86 & 36.68 & Good \\
3 & Paniya & 8.04 & 7.67 & 4.03 & 0.31 & 4.78 & 0.81 & 3.33 & 0.67 & 0.86 & 30.48 & Bad \\
4 & Kuruma & 10.30 & 8.77 & 3.36 & 1.87 & 7.99 & 2.73 & 4.44 & 1.65 & 0.81 & 41.90 & Very good \\
\hline \multicolumn{1}{r}{} & Ranges & & & & & & & & & & & \\
\hline 1 & Kurichyatt & 8.54 & 8.60 & 3.30 & 1.55 & 7.12 & 1.78 & 4.03 & 1.65 & 0.73 & 37.29 & Good \\
2 & Muthanga & 9.45 & 8.21 & 4.29 & 1.21 & 5.64 & 1.65 & 4.97 & 0.90 & 0.82 & 37.18 & Good \\
3 & S. Bathery & 8.66 & 8.62 & 3.18 & 1.32 & 6.46 & 1.97 & 5.40 & 1.06 & 1.00 & 37.65 & Good \\
4 & Tholpetty & 8.46 & 7.70 & 4.05 & 0.61 & 5.32 & 0.93 & 4.43 & 1.02 & 0.84 & 33.36 & Bad \\
\hline
\end{tabular}

Note: $P_{1} \ldots \ldots . . P_{9}$ are parameters (Refer Table 2 for details).

the households addressed their growing concern of continuing the cultivation due to the increased human animal conflict.

Urali tribal community stands next with a score of 36.68 classifies as 'Good'. Uralis, the most versatile and colourful tribal people, is one of the rarest artisan tribes in Kerala. Their participation in Participatory Forest Management and other forest works was found to be higher as compared to the other communities. Their dependence on FRA related livelihood activities are comparatively less. Many of them depend on income from the daily wage earning. They hold an average IFR holding of 0.24 hectares. Due to wild animal attacks and unprofitable income they are reluctant to engage in agriculture. Their dependence on forest for their fuel wood requirements is to the extent of 62.5 per cent.

Kattunaicka is one of the primitive tribes of Kerala, found significantly in Wayanad. As their name denote, the Kattunaickas were the kings of the jungle regions engaged in the collection and gathering of forest produces. They are known as 'Ten Kurumar' since they collect honey from the forest. They have all the physical features of a hilltribe. They had an index score of 36.41 and classified as 'Good'. Their average IFR landholding is 0.263 hectares in the study area next to Kurumas. Along with NTFP collection they are also engaged in agriculture as well as agriculture labour. They are the major community engaged in honey collection in Wayanad. More than 50 per cent of this tribe depends on fuel food alone as an energy source reveals their high dependence on forest ecosystem. In terms of their livelihood activities FRA, 2006 place a major role that gives them legal authority to collect and sell the forest produce.

Among all the tribal communities, paniya tribe found to have the least impact from FRA, 2006 in terms of their livelihood realisation and other socio-economic characters. A wide majority of tribes in state of Kerala hail from the Paniya tribal. They inhabit in the regions of Wayanad and the adjacent parts of Kannur and Malappuram. The Paniyas were sold along with plantations by the landlords as bonded labours. Higher castes were employing them as professional coffee thieves. The present study also reveals their social disadvantages status even now. In all the parameters they found to have the least scores. Even though developmental rights are being distributed irrespective of the tribal community, 17.7 per cent homes were not electrified even now. Their social participation is also comparatively less. They possess an average ILR of 0.064 hectares, most of the cases it was only a habitation right. Even though they were engaged in NTFP collection, the major source of income was agriculture labour. Their literacy levels were also poor, 75.5 per cent are illiterate among them. These also resulted in the poor reachability of act provisions to them and in turn its realization and utilization.

Among all the communities, housing structure and basic infrastructure facility does not varied much. This is because of the equality in the distribution of developmental activities taken up by the Government agencies. All most all the households irrespective of the category had housing structures with basic amenities. 
Between range, except Tholpetty all other ranges had a score of 37 ('Good') indicates the equality in distribution. The bad profile of Tholpetty range was due to $4^{\text {th }}$ (area under FRA) and $6^{\text {th }}$ (income sources) parameters. Interview with tribals in Tholpetty revealed that due to high human animal conflicts, taking up agriculture is impossible in the area. At the same time, they expressed the lack of relief claims for crop damage due to animals from the side of Government. Therefore, majority of the tribals in Tholpetty are going to bordering states (Kodagu-Karnataka) as agriculture laboureres in coffee and pepper plantations even at a very low wage rate. They also expressed their reduced dependence on NTFP collection and marketing due to the increasing population of vermin.

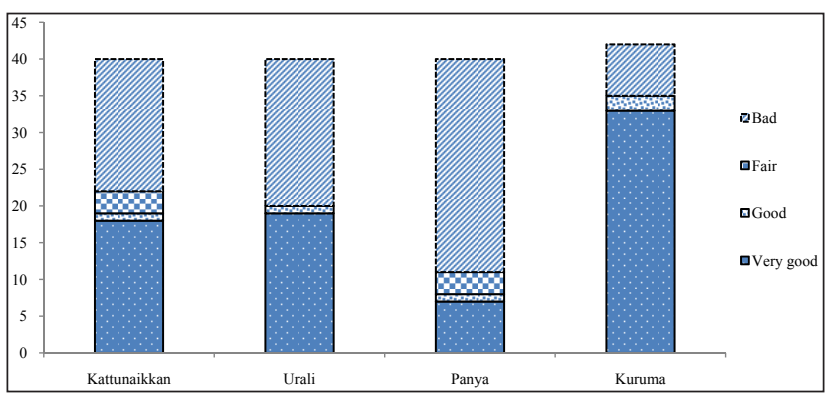

Fig. 2: Socio-economic condition of FRA holders-community wise distribution.

In order to understand, within group situation of households, index score of each household was analysed with the same classification criteria. Frequency distribution is plotted in the graph (Fig. 2). It clearly indicates that among Kattunaickan and Urali communities FRA, 2006 have high as well as low impact on households. Reaping of benefits vary among the community itself. Inter-community conflicts and political influences were the major factors contributing to this inequality as opinioned by the tribal households and various office bearers of the concerned departments. Inherited social class disadvantage was the reason for low impact of FRA among Paniya. Majority of the households were unhappy about the land they received under FRA, 2006. According to them that was not sufficient to find their livelihood even though act promised for it. Lack of proper awareness was another reason for the low performance of FRA among the Paniya tribe.

\section{CONCLUSION}

The central theme of the paper was to throw light on the implementation status and progress of FRA, 2006 and how this approach impacted the socio-economic conditions of the right holders. From the secondary data analysis, it was observed that even though Wayanad is the progressive FRA implemented district in Kerala, only 55.12 per cent of the ILR claims are being distributed. The unreached potential ILR holders are still unknown. Performance of community right distribution is also lagging in the district due to the lack of interest among the concerned departments. It was observed that implementation did not account for the day to day vagaries and social inequalities of the local communities. Out of the major four tribal groups, only one group had high impact on their socioeconomic life. Even though the primary objective was to amend the historic injustice, it was not completely achieved with this approach. The socially disadvantaged class of then are continued to be the one even now without much improvement in their way of life. After 11 years of its implementation the focus of FRA should continue be on the livelihood improvement and land development of tribal communities. Increasing human animal conflict also became a huge concern for these indigenous populations since for most of them forest land is even nowact as an identity of existence. The primary level data analysis also revealed the same. There socio-economic conditions of the communities vary across even though act provisions are for all. This is mainly because of the difference in their community culture \& practices, political influences and intra and inters community conflicts. Therefore act should take care of such difference that really affects the arena of implementation. For the Act to be successful in future it is obligatory that the awareness of the tribals should be improved with reverence to the rights granted to them under the Act. The Government authorities, specifically the forest and tribal welfare departments, who work so closely with the forest dwelling tribals, should take up the role of abetting agency that supports in the knowledge enhancement of communities for better FRA implementation and livelihood enhancement.

\section{REFERENCES}

Alex, A., Vidyasagaran, K., Prema, A. and Kumar, V.S. 2017. Analyzing the livelihood opportunities among the tribes of the Western Ghats in Kerala. Studies of Tribes and Tribals, 14(1): 11-7. 
Anitha, V., Balakrishnan, R. and Krishnakumar, J. 2015. Comunity participation in natural resource conservation: FRA among the Kadars in Kerala India. J. of Environmental Research and Development, 9(3): 669-680.

Bijayashree, S. 2017. Forest Rights Act implementation in Odisha: Redressing the historical injustices. South Asia Research, 37(3): 259-276.

Anonymous. 2012. Recognition of community rights under Forest Rights Act in Madhya Pradesh and Chattisgargh: Challenges and way forward, Final report (2011), Centre for developmental support, pp. 30.

Aggarwal. 2012. Implementation of Forest Rights Act, changing forest landscape and politics of REDD+ in India. Resources, Energy and Development, 8(2): 131-148.

Feroze, S.M. and Chouhan, A.K. 2010. Performance of dairy self-help groups in India: principal component analysis approach. Ind. J. Agric. Econ., 65(2): 308- 318.

Harman, H. 1967. Modern factor analysis. $2^{\text {nd }}$ edition. University of Chicago Press, Chicago.

Khosla, A. and Bhattacharya, P. 2018. Tracking the implementation of FRA, 2006 and its impact on the livelihood of forest dependent people in the state of Tripura. Ind. J. of Humanities and Social Studies, 23(3): 1-13.

Kumar, K., Madhu, S., Tushar, D., Neema, P.B., Neera, S., Sanghamitra, D., Meenal, T., Shruti, A. and Sharachchandra, L. 2016. Promise and performance: Ten years of the FRA in India, Report, Citizens' Report as part of Community Forest Rights-Learning and Advocacy (CFR-LA) process.
Madhusudan, B. 2012. Implementation of FRA: Undoing the historical injustice?, Working paper no 117, Centre for Economic and Social Changes.

Münster, U. and Vishnudas, S. 2012. In the jungle of law: Adivasi rightsand implementation of FRA in Kerala. Economic and Political Weekly, 10(19): 38-45.

Piya, L., Maharjan, K.L. and Joshi, N.P. 2012. Vulnerability of rural households to climate change and extremes: analysis of Chepang households in the mid-hills of Nepal. Paper presented In: International Association of Agricultural Economics (IAAE) Triennial Conference, Brazil, 18-24 August.

Ravindranath, N.H., Rao, S., Sharma, N., Nair, M., Gopalakrishnan, R., Rao, A.S., Malaviya, S., Tiwari, R., Sagadevan, A., Munsi, M., Krishna, N. and Bala, G. 2011. Climate change vulnerability profiles for North east India. Curr. Sci., 101(3): 384-394.

Reddy, G.M. and Nagaraju. 2015. A resurvey of implementation and impact analysis in Andhra Pradesh and Telangana, Cess monograph series- Centre for economic and social studies.

Sathyapalan, J. 2010. Implementation of the FRA in the Western Ghats region of Kerala. Economic and Political Weekly, 10(30): 65-72.

Monthly updates on status and implementation of the scheduled Tribes and other Traditional Forest Dwellers (Recognition of Forest) Act, 2006, Report (30.11.2018), Government of India, Ministry of tribal Affairs. 